\title{
Broadcasting Ulster-Scots: Ulster-Scots media provision in the modern revival period
}

\section{Laura Spence}

\section{(2) OpenEdition \\ Journals}

Electronic version

URL: http://journals.openedition.org/etudesirlandaises/3546

DOI: 10.4000/etudesirlandaises.3546

ISSN: 2259-8863

\section{Publisher}

Presses universitaires de Rennes

\section{Printed version}

Date of publication: 20 December 2013

Number of pages: $95-109$

ISBN: 978-2-7535-2887-1

ISSN: 0183-973X

Electronic reference

Laura Spence, «Broadcasting Ulster-Scots: Ulster-Scots media provision in the modern revival period », Études irlandaises [Online], 38-2 | 2013, Online since 20 December 2015, connection on 01 May 2019. URL : http://journals.openedition.org/etudesirlandaises/3546 ; DOI : 10.4000/ etudesirlandaises.3546

This text was automatically generated on 1 May 2019.

(c) Presses universitaires de Rennes 


\title{
Broadcasting Ulster-Scots: Ulster-Scots media provision in the modern revival period
}

\author{
Laura Spence
}

\section{Introduction}

1 As a media organisation which aims to reflect and report on aspects of contemporary local society, BBC Northern Ireland Television (BBC One NI and BBC Two NI) and BBC Radio Ulster/Foyle are at the heart of Northern Ireland, reflecting the diversity of community and cultural life.

In very general terms, the public in Northern Ireland started to become aware of the term "Ulster-Scots" around the time of the Northern Ireland Peace Agreement of $1998^{1}$ when a Cross Border Language Body was established between Northern Ireland and the Irish Republic. Two years later, in March 2000, Ulster-Scots was granted Part 2 status under the European Charter for Regional or Minority Languages, signed by the United Kingdom Government: this obliged the Northern Ireland Government to promote the Ulster-Scots language along with its associated culture and history; and that commitment was reinforced in the St Andrews Agreement of 2006.

3 The real beginning of Ulster-Scots awareness in Northern Ireland, however, predated 1998. The Ulster-Scots Language Society ${ }^{2}$ had been formed in 1992 and was actively publishing and promoting Ulster-Scots language and literature. Its best-selling publications The Hamely Tongue $e^{3}$ and Ulster-Scots Grammar ${ }^{4}$ were highly acclaimed, and its annual in-house journal Ullans was receiving a considerable number of contributions. The Ulster-Scots Heritage Council ${ }^{5}$, established in 1995, was providing support to cultural and historic projects. 
This growing interest in Ulster-Scots required BBCNI to produce resources in and about Ulster-Scots, an intention reinforced by the BBC's Charter commitment ${ }^{6}$ to minority languages.

\section{Pre-Agreement Ulster-Scots Programming}

Before 1998, there was already some Ulster-Scots content in BBCNI programming. For example, in April 1975, the poet John Hewitt wrote and presented a programme for BBC Radio Ulster called The Rhyming Weavers of Ulster? ${ }^{7}$. In the introduction to his script, he said:

Life 150 years ago in Counties Antrim and Down revolved around the manufacture of linen. This was mainly the case in the north-eastern counties where the population was mostly descended from the Scots planters of the early $17^{\text {th }}$ century. Many weavers and farmers wrote poems and songs about their daily lives, amongst many other things, which are documented in a stream of little books written in the 1800 s by the Rhyming Weavers.

Nowadays, there is a great revival of interest in the Rhyming Weavers and, in fact, the work of John Hewitt is the subject of a travelling exhibition and website ${ }^{8}$ created by the University of Ulster.

7 Hewitt's pioneering programme was one of a number of broadcasts produced by the BBC Schools Education Department from the 1950s onwards. During this period, a well-known local historian and broadcaster, Sam Hanna Bell, was ranging the glens and hills of County Antrim and further afield, tape-recording the voices of hill farmers and stonemasons, fishermen and artisans, and recording an essentially Ulster-Scots lifestyle and accent - before they were generally recognised as such.

It must be noted that radio recordings during this period were made on quarter-inch tape which was prohibitively expensive; and while a few rare programmes have been identified in the $B B C$ archives, many valuable recordings were taped over once the programme had aired. An important piece of work remains to be done in thoroughly exploring the extant tapes to rediscover, catalogue and make available any early UlsterScots material.

In Spring 1995, ten essays were commissioned by BBC Radio Ulster featuring participants discussing what it meant to be Protestant in Northern Ireland. This series, entitled of Planter Stock ${ }^{9}$, considered issues such as music, humour, sport, faith and the Scotch-Irish in America, and contributors including historians and community workers talked about their sense of identity.

The following year, in Spring 1996, a six-part radio series called Pioneers and Presidents ${ }^{10}$ looked at the Scotch-Irish over the Atlantic, considering the impact of "this bold and hardy race" on politics, faith, music and culture, etc.

11 In subsequent years, some of the contributors to these two radio series went on to become actively involved in the Ulster-Scots revival movement.

\section{Post-Agreement Ulster-Scots Programming}

12 In Spring 1999, shortly after the Belfast Agreement, BBC Radio Ulster transmitted its first consciously "Ulster-Scots" broadcast. A six-part radio series simply called The Ulster-Scots 
${ }^{11}$ provided an introduction to the history, culture, language and literature of the UlsterScots. The programmes looked at historical events such as: the Plantation of the 1600 s and the 1798 Rebellion; the history and influence of the Scotch-Irish in the revolution and development of the government of the United States; the impact of the Ulster-Scots in the $19^{\text {th }}$ century and the writings of the Weaver Poets; the nature and beliefs of Ulster-Scots speakers, observers and researchers; and the future of the Ulster-Scots language and culture in the light of what was then described as "a recent government announcement".

Meanwhile, an independent Irish production company called Igloo Productions was filming a fly-on-the-wall documentary about two bachelor brothers living on a remote farm in the Glens of Antrim. Us Boys ${ }^{12}$ focused a camera on Ernie and Stewart Morrow, both in their eighties, and living without electricity or modern comforts as they farmed twenty cattle, a hundred sheep and countless fowl. This programme was broadcast on RTE in 1999 to high acclaim, and has recently been re-broadcast in 2012 as part of the BBCNI series Santer ${ }^{13}$.

It is very telling that the editors of Us Boys were obliged to use sub-titling (often inaccurately) to translate the broad vernacular speech used by the Morrow brothers whose dialogue was so rich in terms of Ulster-Scots vocabulary that almost every conversation required translation for the audience. While the "bygone days" lifestyle and dense tongue of the Morrows are increasingly rare, there are still some people, usually older and most often living in rural locations, who do still speak a naturally broad UlsterScots, and it is vital that these people are identified and recorded before it is too late. While much important work has been done in this respect by the Ulster-Scots Language Society, there is a real impetus for additional fieldwork.

\section{An Ulster-Scots Night - January 2000}

With legislation in place and a growing interest in Ulster-Scots language and culture, BBC Two NI decided to mark Burns Night in January 2000 with an "Ulster-Scots Night"14. This was a particularly appropriate date since Robert Burns is venerated in Ulster with $25^{\text {th }}$ January firmly fixed in the local cultural calendar. The television schedule consisted of five strands, the first of which, A Braw Brew of Words, was recorded at a County Antrim Burns Night and featured music, poems, stories and poetry with an Ulster-Scots and Scottish flavour.

16 In a specific nod to Ulster-Scots musical culture, the second element of the evening, $A$ Bunch of Thyme, featured a concert in Belfast's Waterfront Hall with various musicians performing Scots and Ulster-Scots music. Kins o Men for aa That was an informative documentary presented by well-known poet, Tom Paulin, who looked at the historic and current position of Ulster-Scots, providing some context for the evening through a series of interviews with enthusiasts and academics. The fourth strand, Braid Scots, was an independently-produced programme from 1996 which considered the history and use of Ulster-Scots language and literature. The evening concluded with At's tha Wye A Taak, a series of vox-pops in which people discussed what Ulster-Scots meant to them personally. This evening of Ulster-Scots programming, a first for BBCNI, attempted to balance elements of language, culture and history. It featured children, scholars and native speakers and, although the narrative was in English, many of the contributors spoke in Ulster-Scots. 


\section{Ulster-Scots Online} help preserve and revive the language and this option was preferred by academics and 
revivalists. However, from a broadcasting point of view, the light form would be more accessible to younger people and to a wider audience and therefore would result in higher listening figures. The solution seemed to be a programme presented by authentic native speakers, delivering a fairly accessible form of Ulster-Scots - but with topical consideration and debate on issues of language and vocabulary. The most important thing was to get the audience to tune in and engage with the debate, rather than being deterred through hearing too dense a version of the language.

This debate then gave rise to the related issue of the "authenticity" of presenters and contributors. It has always proven difficult to persuade natural speakers of braid Scotch to speak in relatively formal situations, especially when they are being recorded. Off-air, their conversation is naturally vernacular, yet once the BBC tape-recorder is turned on, they instinctively switch to standard English. When recruiting presenters for A Kist $o$ Wurds, the BBC production team quickly realised that anyone who had "learned" to speak Ulster-Scots was unlikely to come across as genuine and would be treated rather sceptically by the audience. However, the search for authentic native speakers who were prepared to broadcast in the vernacular, resulted in a very small pool of potential presenters. Over the years, a number of presenters have now been found from across the Ulster-Scots heartland counties of Down, Antrim, Londonderry and Donegal, and this team is occasionally supplemented with guest or specialist presenters.

In terms of "cultural" broadcasting, a significant issue for the Kist o Wurds production team was and remains the difficulty of extracting Ulster-Scots culture from the remainder of local cultural traditions. While pipe bands and Scottish country or highland dancing are frequently cited as examples of Ulster-Scots culture, are they Scottish or Ulster-Scottish? The fact that there are strong continuing links between the planter population of Ulster and Scotland means that an overlap is inevitable and, by and large, the audience seems to accept this.

The past decade has seen the creation of various new Ulster-Scots cultural societies, organisations and events: for example, there are Ulster-Scots summer schemes, festivals, bus tours and competitions as well as fresh interest in such aspects of Ulster-Scots culture as cookery, architecture, sport, genealogy and music. This again raises a potential debate over authentic Ulster-Scottishness, but there is no doubt that such developments have increased awareness of Ulster-Scots culture among the public. From a media production point of view, these initiatives provide colourful material for radio and television features as well as potentially introducing new audiences to Ulster-Scots broadcasting. For example, if a local school puts on an Ulster-Scots play and this is recorded as a package for A Kist o Wurds, the children and their families will tune in and maybe listen to the other articles on the programme, thereby potentially fostering an interest in some other aspect of Ulster-Scots.

Striking the correct balance between language, history and culture is an important consideration for broadcasters. Undoubtedly modern Ulster-Scots culture is vibrant, accessible and attractive to audiences - but without the history, language and literature it becomes decontextualized and less authentic. The challenge facing producers is to integrate all facets of Ulster-Scots into a distinctive and mutually-supportive package.

In 2014, A Kist o Wurds remains BBCNI's flagship Ulster-Scots programme. Now in its eleventh year with over 350 episodes, it has been produced externally for BBCNI by an independent company for the past few years, and features items from across Ulster and beyond. A Kist o Wurds has reported on all the key Ulster-Scots events, publications and 
resources over the past decade and, as such, forms a valuable commentary on the revival movement.

\section{Ulster-Scots in the Noughties} undertook the biggest survey of regional English ever undertaken in the UK. This "Voices Project" aimed to present a snapshot of the many ways we speak in the early 21st century - and at its heart was a ground-breaking recording of 1,000 voices across the UK from farmers in the Glens of Antrim to black Londoners in Peckham, from Treorchy to Taunton, mapping the geography of the UK in accents and dialects. In Ulster, participants came from four traditional Ulster-Scots speaking areas ${ }^{22}$ and the researchers considered similarities and differences in phrases and vocabulary. For example, they asked UlsterScots native speakers to discuss words they would use for moods, places, food and drink and this then led on to round-table discussions on subjects ranging from agriculture to the weather. These Ulster-Scots voices are available online on the Voices website ${ }^{23}$ in perpetuity and will no doubt form a useful point of reference for similar future projects.

By January 2006, A Kist o Wurds had acquired a loyal listenership and its regular presenters and contributors were well-known to the audience. For Burns Night on BBC Two NI, James Fenton, author of The Hamely Tongue, and radio broadcaster, Liam Logan, presented an innovative television programme called Iver Hantin Echas ${ }^{24}$ investigating Ulster-Scots language, literature and culture. Fenton read a selection of his Ulster-Scots poems and journeyed round some of the places which had inspired them, while onscreen, the words and phrases were highlighted to show the audience written UlsterScots. On a visit to a north Antrim primary school, Fenton and Logan went to meet children studying the poetry and using the vocabulary. This programme appealed to a very wide audience in terms of age and geographic interest. 
2006 also marked a significant anniversary in the Ulster-Scots history calendar, commemorating the $400^{\text {th }}$ anniversary of the 1606 settlement of the Ards Peninsula in County Down, by two Scottish lairds, James Hamilton and Hugh Montgomery. BBCNI broadcast a documentary programme called Dawn of the Ulster-Scots ${ }^{25}$ looking at the impact of this influx of Scottish settlers in Ulster and its lasting legacy. This 1606 event was one of the earliest Ulster-Scots milestones: subsequently BBCNI has marked a few other anniversaries with Ulster-Scots connections such as the Flight of the Earls, the Plantation of Ulster, the launch and subsequent loss of RMS Titanic, and the signing of the Ulster Covenant to name a few. Further anniversaries are forthcoming and will present useful opportunities for reflection on the Ulster-Scots contribution to significant events in local history.

In 2007, an independently-produced TV series was commissioned and broadcast by BBCNI. A Dander with Drennan ${ }^{26}$ featured Ulster-Scots musician and storyteller Willie Drennan, journeying on foot around Ulster and beyond, exploring churches, graveyards, battle sites and other places of Ulster-Scots historical significance. As he travelled, he met up with Ulster-Scots enthusiasts of all ages and from all walks of life, and elements of language, literature, history and culture were carefully balanced. Although a second series was broadcast in 2008, no further programmes were commissioned. Nonetheless this primetime programme yet again brought Ulster-Scots issues into the public arena and gave rise to considerable debate.

\section{Appointment of Ulster-Scots Producer and Launch of BBC Ulster-Scots Website}

In May 2009, BBCNI appointed a full-time Ulster-Scots Producer to increase the range and impact of Ulster-Scots related output through dedicated online and outreach work and the production of a bespoke website.

The BBC NI Ulster-Scots website ${ }^{27}$ was developed throughout 2010 and was formally launched in May 2011. An ambitious project in scale, it was designed to meet the requirements of the audience and offer learning materials for adults and children, audio and video clips, a one-stop-shop for Ulster-Scots resources, news of events and organizations, and a forum where the Ulster-Scots community could interact and promote their own work. Following the launch, the site was showcased in venues across Ulster, in partnership with the University of Ulster. A second phase allowed users to create a personalized area of the site where they could bookmark and tag useful clips or assets, as well as commenting on the "Word of the Day" vocabulary feature.

\section{Ulster-Scots Resources for Children}

In recent years, a significant curriculum change in Northern Ireland has been the new Primary Languages Programme ${ }^{28}$. The government accepted a recommendation from the Council for Curriculum Examinations and Assessment (CCEA) that language learning should begin in primary schools and not be left until age 11 by which time language learning capability has actually begun to decline. With this in mind, BBCNI created a number of Ulster-Scots language learning resources specifically for children. 

invention rather than an authentic chapter of local history. In 2012, BBCNI commissioned local historian, Dr Jonathan Bardon ${ }^{32}$, to write the history of Ulster-Scots in sixty short episodes. A Narrow Sea ${ }^{33}$ explored the colourful and complex story of Scotland's connections with Ulster from the Ice Age to the present day, outlining the main events and personalities in an unbiased and informed way. The series was broadcast on BBC Radio Ulster and was also made available as a podcast: in fact, A Narrow Sea was the most downloaded podcast for Radio Ulster over the period with 127,452 requests over three months: this staggering statistic shows the huge appetite there is for both well-told history and Ulster-Scots material.

The Tellytales ${ }^{29}$ series is a collection of animated myths, legends and fairytales from round the world, told in Ulster-Scots. The programmes, scripts and performance notes are available online for school or family / individual use and the vocabulary from the series is incorporated into the 'Word of the Day' feature on the BBC website to allow for additional language work.

A second interactive website looks at the life and mission of Patrick, patron saint of Ireland. Launched on $17^{\text {th }}$ March 2010, St Patrick's Journey ${ }^{30}$ is a unique learning resource offered in three languages - English, Irish and Ulster-Scots. The site encompasses flash animations and games and is narrated by a native Ulster-Scots speaker: it was shortlisted in 2011 for a Celtic Film \& TV Media Award. As with Tellytales the focus of this project was very much on language and allowing children to hear Ulster-Scots spoken while simultaneously the written words appeared on screen.

en from nursery age to Key Stage 3 (age 14) covering various aspects of Ulster-Sc culture including language, literature, cookery, music, the Scotch-Irish in America, the Plantation, and famous Ulster-Scots. Five sample lessons for KS3 Curriculum work ${ }^{31}$ were based on poems written in the local vernacular by County Antrim bards from the $18^{\text {th }}, 19$ th and $20^{\text {th }}$ centuries.

Although these resources are freely available online, they would be of greater use to local schools and teachers if they were signposted as part of a wider curriculum initiative to support the teaching of Ulster-Scots. This paper is not the forum for such a discussion but hopefully this is something which will be addressed under the Department of Culture, Arts and Leisure Strategy for Ulster-Scots, mentioned later in this paper.

\section{Broadcasting Ulster-Scots History}

Some periods in Ulster's history such as the $17^{\text {th }}$ century Plantation, the arrival of Presbyterianism, the 1798 Rebellion, the industrialisation of Belfast, and the Great Irish Famine of the mid $19^{\text {th }}$ century, have had a lasting impact on both landscape and people. These themes were explored in two history series broadcast in 2011 and 2012. Hidden History $^{34}$ was written and presented by historian, Dr Éamon Phoenix of Stranmillis University College in Belfast who brought the history to life through focusing on events, personalities, architecture and landscape. Although the programmes had a focus on Ulster-Scots history, Dr Phoenix placed key events within a shared context showing how history impacted on all people throughout Ulster. This was and is an important 
consideration for broadcasters as it is important to stress that Ulster-Scots bridges communities and classes in Northern Ireland.

\section{Ulster-Scots Drama} developed two series entitled Weaving Words ${ }^{43}$ in 2011-2012. Ten programmes, scripted by specialist academics, considered the life and work of a number of vernacular poets of the eighteenth to the twentieth centuries, many of them weavers, and set their writing in the context of contemporary events. Dr Jennifer Orr, Christopher Tower Lecturer in English Poetry, Christ Church, Oxford and Fellow in English An Chomhairle um Thaighde in Eirinn at Trinity College Dublin, wrote to BBCNI in 2012, saying: 
I regularly use resources from $\mathrm{BBC}$ Ulster-Scots in my teaching and research; and can testify that my colleagues at the University of Glasgow use the Weaving Words resources on the Ulster poets for both undergraduate and master's teaching in Scottish Literature. A second example from BBC Scotland - the works of Robert Burns - has been similarly successful. This is an up-and-coming area of scholarship and teaching which the BBC's resources have made possible. I trust that the BBC will uphold their strategic plan for Ulster-Scots which promised to "create and maintain a website", particularly given the highly valuable resources that you have built up over the last four years. I number among these A Narrow Sea, Weaving Words, St Patrick's Journey, and the various dramatic pieces that have been produced. These are, among the other Ulster-Scots productions, the resources which have true academic and cultural value and are important to preserve ${ }^{44}$.

\section{The Ulster-Scots Broadcast Fund ${ }^{45}$}

51 In 2011, the Ulster-Scots Broadcast Fund (USBF) was set up to ensure that the heritage, culture and language of Ulster-Scots were expressed through moving image and to foster the Ulster-Scots independent production sector in Northern Ireland. Overseen by Northern Ireland Screen, the Fund provides financial support for the production of high quality film, television or other moving image projects relating to the Ulster-Scots heritage, culture and language in Northern Ireland. The Fund runs until 2015.

BBCNI has so far broadcast a number of independent TV commissions funded by the USBF, including Santer ${ }^{46}$, An Independent People ${ }^{47}$, Dan Cruickshank's Written In Stone ${ }^{48}$, An Ode to Burns and Ulster ${ }^{49}$, Eddie Reader's Rabbie Burns Trip ${ }^{50}, 12$ Miles: The Narrow Sea ${ }^{51}$, and The Ulster Covenant ${ }^{52}$.

\section{Governmental Plans for Ulster-Scots}

53 The Department of Culture, Arts and Leisure (DCAL), in 2011, created a "Ministerial Advisory Group on the Ulster Scots Academy" (MAGUS) 53 to promote research, knowledge and understanding of Ulster-Scots language, history and cultural traditions.

The following year, 2012, MAGUS prepared a consultative document ${ }^{54}$ containing proposals for a strategy for Ulster-Scots language, heritage and culture. Section 11 concerned media and the ambition to increase the volume of Ulster-Scots language, heritage and culture programming on television; and develop a dedicated Ulster-Scots language, heritage and culture radio station. At time of writing, the strategy is still being completed.

\section{The Future}

55 Although much important groundwork has been done by BBCNI and others in the area of Ulster-Scots broadcasting in the modern revival period, particularly in terms of radio and online provision, the USBF and DCAL's future plans will undoubtedly allow for more programmes and media resources in coming years.

The issues identified in this paper, regarding the extent, form and balance of Ulster-Scots content, will no doubt continue to exercise production teams as they weigh up the needs of revivalists and enthusiasts, and attempt to present attractive resources across a variety 
of emerging media platforms. There are new players coming into the field as Ulster-Scots "apps" are being developed for smart-phones; tourist trails and experiences signpost visitors to places of interest; and cultural organisations offer a variety of talks, resources and opportunities for engagement with Ulster-Scots. It is up to producers to distil the essence of the modern-day Ulster-Scots phenomenon and present it in a way which will engage new and younger audiences and ensure that Ulster-Scots remains a familiar designation and presence within broadcasting.

\section{NOTES}

1. <http://peacemaker.un.org/node/1697>

2. <www.ulsterscotslanguage.com/>

3. James Fenton, The Hamely Tongue: A Personal Record of Ulster-Scots in County Antrim, 3rd edition, Belfast, The Ullans Press, 2007.

4. Philip Robinson, Ulster-Scots: A Grammar of the Written and Spoken Language, 2nd edition, Belfast, The Ullans Press, 2007.

5. Note - the USHC is now the Ulster-Scots Community Network. See: <www.ulsterscots.com/>

6. <www.bbc.co.uk/northernireland/audiencecouncil/news/minority_eng.shtml>

7. <www.bbc.co.uk/programmes/p009470r>

8. <www.arts.ulster.ac.uk/ulsterpoetry/onlinecollection.php>

9. <www.bbc.co.uk/programmes/p00715sg/episodes/guide>

10. <www.bbc.co.uk/programmes/p007l5pq/episodes/guide>

11. <www.bbc.co.uk/programmes/p005vyfc/episodes/guide>

12. <http://igloofilms.ie/project/us-boys/>

13. <www.bbc.co.uk/programmes/b015zmgf>

14. <www.bbc.co.uk/programmes/p007k1v2>

15. <www.bbc.co.uk/northernireland/learning/history/stateapart/>

16. <www.bbc.co.uk/northernireland/learning/history/stateapart/agreement/culture/ support/cul2_c051.shtml>

17. <www.bbc.co.uk/history/british/plantation/>

18. <www.bbc.co.uk/programmes/b007d4s0>

19. First published in Ullans and later reprinted in A Blad o Ulster-Scotch frae Ullans (both published by The Ullans Press). The text of this paper can be read online at: $<$ www.ulsterscotslanguage.com/en/texts/test/>

20. <www.bbc.co.uk/programmes/p007k1tc>

21. <www.bbc.co.uk/northernireland/schools/11_16/music/traditions/index.shtml> 
22. Kilwaughter in south Antrim, Lisnagunogue in north Antrim, St Johnston in Donegal and Greyabbey in County Down.

23. <www.bbc.co.uk/northernireland/voices/ulsterscots/index.shtml>

24. Trans. "Ever Haunting Echoes" - taken from James Fenton's poem "On Slaimish", which was first published in Ullans: The Magazine for Ulster-Scots, 9/10, Wunter 2004, Belfast, Ullans Press, 2004, p. 54. See: <www.ulsterscotslanguage.com/en/books/ulster-scotspoetry-books/on-slaimish/>

For the BBC programme, see: <www.bbc.co.uk/programmes/p00bpk5z>

25. <www.bbc.co.uk/ulsterscots/library/1606-the-dawn-of-the-ulster-scots>

26. <www.bbc.co.uk/programmes/bo0cz7xx/episodes/guide>

27. <www.bbc.co.uk/ulsterscots>

28. <www.deni.gov.uk/languages_for_the_future.pdf>

29. <www.bbc.co.uk/ulsterscots/library/tellytales>

30. <www.bbc.co.uk/northernireland/saintpatrick/>

31. <www.bbc.co.uk/ulsterscots/children/ailsa>

32. <http://en.wikipedia.org/wiki/Jonathan_Bardon>

33. <www.bbc.co.uk/ulsterscots/library/a-narrow-sea>

34. <www.bbc.co.uk/programmes/b00z0dyp>

35. <www.bbc.co.uk/programmes/boot3nsk>

36. Published by R Carswell \& Son Ltd, Belfast, 14th December 1901 - see also <bbc.co.uk/ ulsterscots/find-out-more/books/robins-readings>

37. <www.bbc.co.uk/ulsterscots/library/a-wumman-for-oor-wullie>

38. <www.bbc.co.uk/ulsterscots/library/liza-lowrys-retirement>

39. <www.ulsterscotslanguage.com/en/books/ulster-scots-novels/the-auld-meetinhoose-green/>

40. <www.ulsterscotsagency.com/education/pat-and-plain-drama-series/>

41. <www.bbc.co.uk/programmes/b00ph5z0>,

<www.bbc.co.uk/programmes/b00vlz5d> <www.bbc.co.uk/programmes/b017l3w7>

42. <www.bbc.co.uk/programmes/b00ph8wq>

43. <www.bbc.co.uk/programmes/p00y1rqb/episodes/guide>

44. The text is reproduced with the permission of the author.

45. <www.northernirelandscreen.co.uk/categories/95/ulster-scots-broadcast-fund.aspx>

46. <www.bbc.co.uk/programmes/b015zmgf>

47. <www.bbc.co.uk/programmes/b01rl33q>

48. <www.bbc.co.uk/programmes/b01r5t40>

49. <www.bbc.co.uk/programmes/b01q5259>

50. <www.bbc.co.uk/programmes/b01q5257>

51. <www.bbc.co.uk/programmes/b01pbpg3>

52. <www.bbc.co.uk/programmes/b01mzlgw>

53. <www.dcalni.gov.uk/index/language-cultural-diversity-r08/ulster-scots.htm> 
54. $<$ www.dcalni.gov.uk/index/language-cultural-diversity-r08/

consultation_on_the_strategy_for_ulster_scots_language_heritage_and_culture.htm>

\section{ABSTRACTS}

In recent years $\mathrm{BBC}$ Northern Ireland (BBCNI) has responded to a growing interest in Ulster-Scots language and culture by producing a range of Ulster-Scots television and radio programmes and online media. This paper broadly summarises BBCNI output to date and also considers some of the issues faced by producers when creating Ulster-Scots resources.

Depuis quelques années $\mathrm{BBC}$ Northern Ireland $(\mathrm{BBCNI})$ a réagi à l'intérêt grandissant pour la langue et la culture Ulster-Scots en produisant un éventail d'émissions pour la télévision, la radio et l'internet avec une thématique Ulster-Scots. Cet article propose une vue générale de la production de la BBCNI jusqu'à nos jours et évalue les problèmes qui se posent lors de la création de ressources Ulster-Scots.

INDEX

Mots-clés: radio, télévision, héritage culturel, Irlande du Nord, langues en Irlande - Ulster-Scots Keywords: Ulster-Scots, cultural heritage, languages in Ireland - Ulster-Scots, Northern Ireland

\section{AUTHOR}

\section{LAURA SPENCE}

Radio and Online Producer, BBC Northern Ireland 